\title{
Feasibility of ultrasound-assisted optimized process of high purity rice bran protein extraction
}

\author{
Sílvia Bernardi ${ }^{1}$ Daneysa Lahis Kalschne ${ }^{1}$ Anne Luize Lupatini Menegotto ${ }^{1}$ iD \\ Eder Lisandro Moraes Flores ${ }^{2}$ D Juliano Smanioto Barin ${ }^{3}$ (D) \\ Renata Hernandez Barros Fuchs ${ }^{4}$ (D) Eliane Colla ${ }^{1}$ (D) Cristiane Canan ${ }^{1 *}$ (D)
}

\author{
${ }^{1}$ Departamento de Alimentos, Universidade Tecnológica Federal do Paraná (UTFPR), 85884-000, Medianeira, PR, Brasil. E-mail: canan@utfpr.edu.br \\ ${ }^{*}$ Corresponding author. \\ ${ }^{2}$ Departamento de Química, Universidade Tecnológica Federal do Paraná (UTFPR), Medianeira, PR, Brasil. \\ ${ }^{3}$ Departamento de Tecnologia e Ciência dos Alimentos, Universidade Federal de Santa Maria (UFSM), Santa Maria, RS, Brasil. \\ ${ }^{4}$ Departamento de Alimentos, Universidade Tecnológica Federal do Paraná (UTFPR), Campo Mourão, PR, Brasil.
}

\begin{abstract}
Rice bran is a by-product of the rice milling process, found worldwide in abundance and highlighted due its protein content. This study optimized the conditions for ultrasonic-assisted extraction of protein from defatted rice bran (DRB) and characterized the rice bran protein concentrate (RBPC). A sequential strategy of experimental design was employed; the effect of pH, temperature, ultrasound exposure time, and amplitude were evaluated regarding the percentage of protein extraction by a Full factorial design (FFD) with a fixed frequencies (FFD-A: $37 \mathrm{kHz}$; FFD-B: $80 \mathrm{kHz}$ ). Subsequently, the percentage of protein extracted was optimized employing a Central composite rotatable design (variables: $p H$ and ultrasound exposure time) and RBPC obtained was characterized regarding chemical and functional properties. The $\mathrm{pH}$ and ultrasound exposure time had positive effect $(P \leq 0.05)$ on percentage of protein extraction; moreover, $37 \mathrm{kHz}$ frequency was more effective in protein extraction. The optimized condition (frequency: $37 \mathrm{kHz}$; temperature: $30{ }^{\circ} \mathrm{C} ; \mathrm{pH}: 10$; ultrasound exposure time: 30 min;

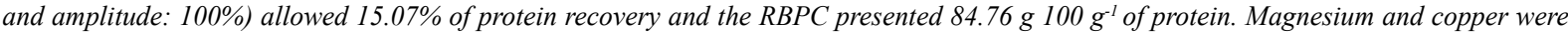
the main mineral in RBPC (34.4 and $25.5 \mu \mathrm{g} \mathrm{g} \mathrm{g}^{-1}$, respectively), while leucine was the limiting amino acid (0.42) and threonine presented the highest chemical score (1.0). The RBPC solubility was minimal at pH 4 and higher at pHs 6-10; the water and oil absorption capacity were higher than bovine serum albumin (BSA) and the emulsifying capacity was comparable to BSA, with a suitable stability. It was possible to obtain a higher purity RBPC than described in the literature, due to the optimization in the extraction process steps, with functional properties suitable for application in food products, especially emulsified ones.
\end{abstract}

Key words: amino acid, alkaline extraction, by-product, defatted rice bran, functional properties, sequential strategy of experimental design.

Viabilidade do processo otimizado assistido por ultrassom para extração de proteína de farelo de arroz de alta pureza

RESUMO: O farelo de arroz é um subproduto do processo de moagem do arroz, encontrado em abundância em todo o mundo e destacado devido ao seu teor de proteinas. Este estudo otimizou as condições para a extração assistida por ultrassom da proteina do farelo de arroz desengordurado (DRB) e caracterizou o concentrado de proteina do farelo de arroz (RBPC). Uma estratégia sequencial de desenho experimental foi empregada; o efeito do $\mathrm{pH}$, temperatura, tempo de exposição ao ultrassom e amplitude foram avaliados em relação à porcentagem de extração proteica por um Delineamento Fatorial Completo (FFD) com frequências fixas (FFD -A: $37 \mathrm{kHz} ; \mathrm{FFD}-\mathrm{B}$ : $80 \mathrm{kHz}$ ). Posteriormente, a porcentagem de proteina extraída foi otimizada empregando um Planejamento Composto Central (variáveis: pH e tempo de exposição ao ultrassom) e o RBPC obtido foi caracterizado quanto às propriedades químicas e funcionais. O pH e o tempo de exposição ao ultrassom tiveram efeito positivo $(P \leq 0,05)$ na porcentagem de extração proteica. Além disso, a frequência de $37 \mathrm{kHz}$ foi mais eficaz na extração de proteínas. A condição otimizada (frequência: $37 \mathrm{kHz}$; temperatura: $30{ }^{\circ} \mathrm{C}$; $\mathrm{pH}$ : 10 ; tempo de exposição ao ultrassom: $30 \mathrm{~min}$; e amplitude: 100\%) permitiu 15,07\% de recuperação de proteínas e o RBPC apresentou 84,76 $\mathrm{g} 100 \mathrm{~g}^{-1}$ de proteina. Magnésio e cobre foram os principais minerais da $\operatorname{RBPC}\left(34,4\right.$ e $25,5 \mu \mathrm{g} \mathrm{g}^{-1}$, respectivamente), enquanto a leucina foi o aminoácido limitante (0,42) e a treonina apresentou o maior escore químico (1,0). A solubilidade do RBPC foi mínima em pH 4 e superior em pH 6-10; a capacidade de absorção de água e óleo foi maior que a albumina sérica bovina (BSA) e a capacidade de emulsificação foi comparável à BSA, com uma estabilidade adequada. Assim, foi possível obter um RBPC com elevada pureza, maior do que o descrito na literatura, devido à otimização nas etapas do processo de extração, com propriedades funcionais adequadas para aplicação em produtos alimenticios, principalmente emulsificados.

Palavras-chave: aminoácido, extração alcalina, subprodutos, farelo de arroz desengordurado, propriedades funcionais, estratégia sequencial de delineamento experimental.

\section{INTRODUCTION}

Rice bran is a by-product from rice nutritionally rich, especially due its protein composition (approximately 15\%), drawing as an alternative source in contribution of this nutrient (ROMERO, 2015). Consequently, rice bran proteins might be a valuable component in food formulation, 
supplying important nutritional but also functional properties, such as foaming, emulsifying and gelation capacity (PHONGTHAI et al., 2016a; HOU et al., 2017). In this context, it is evident the improvement on studies of rice bran protein functional properties, such as, the application of this protein on different food formulations.

The low application of rice bran protein as food ingredient is associated with their difficult obtainment. Rice bran proteins have different degrees of hydrogen, disulfide bonds that keep the polypeptides strongly bonded and different degrees of hydrophobicity may difficult the protein extraction process; thus, the conventional method in isolating rice bran proteins is alkali extraction followed by precipitation at the isoelectric $\mathrm{pH}$ (ROMERO, 2015). In this context, physical, enzymatic, and mechanical treatments may be associated in order to the release rice protein from cells. The ultrasonic waves is a physical technique highlighted as an alternative to reduce the extraction time and efficiency of rice bran protein extraction (CHITTAPALO et al., 2009; PHONGTHAI et al., 2016a).

Currently, the use of ultrasound for solid-liquid extraction have been highlighted due to high reproducibility, shorter time consumption, convenience, reduced consumption of solvent, and lower energy input (PHONGTHAI et al., 2016a). Mechanical effects of ultrasound provide a greater penetration of solvent into cellular materials and improves mass transfer in organic compounds extraction from a tissue (CHEMAT et al., 2011), showing as an alternative in the improvement of rice bran protein extraction.

Thus, the aim of this study was to evaluate the rice bran extraction process through ultrasonic waves in an alkaline medium for further protein concentrate precipitation. A sequential strategy of experimental design was employed in order to optimize the conditions for protein obtainment. Moreover, the protein concentrate composition and functional properties was evaluated.

\section{MATERIALS AND METHODS}

\section{Materials}

Defatted rice bran (DRB) in pellets have been supplied by Indústria Riograndense de Óleos Vegetais (Irgovel, Pelotas-RS, Brazil) - 2013/2014 harvest. Prior to protein extraction study, the DRB had been ground using a cutting mill (Solab, SL 31 Willye Type, Brazil) with 70 mesh average particle size, packed in polyethylene bags and stored at $-20{ }^{\circ} \mathrm{C}$. All chemical reagents used have been commercially purchased from different sources.

Sequential strategy of experimental design used for deffated rice bran (DRB) protein extraction

The use of ultrasonic waves in the alkaline medium has been studied in order to maximize the conditions for DRB protein extraction and a summary of experiments conducted in the present study were detailed in figure 1.

Initially, two fractional factorial designs (FFDs) $2^{4-1}$ (3 central points, totalling 11 runs)

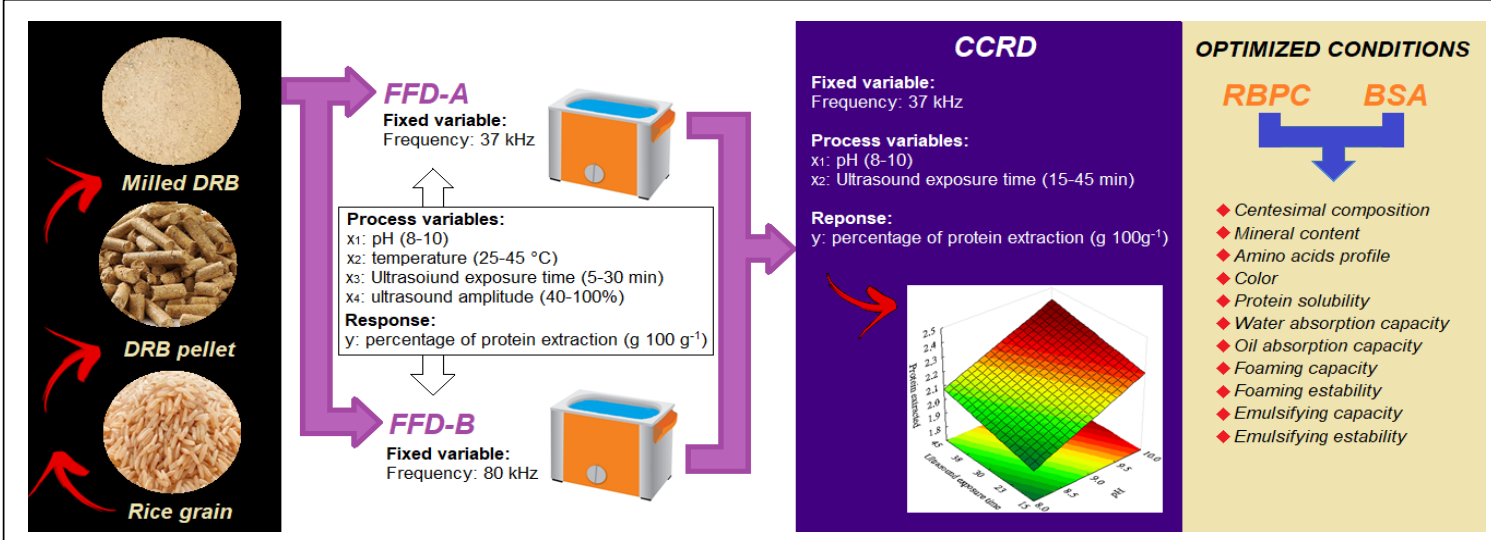

Figure 1 - Scheme of experiments conducted in the sequential strategy of experimental design and rice bran protein concentrate (RBPC) characterization.

DRB: defatted rice bran; FFD-A: Full factorial design A; FFD-B: Full factorial design B; CCRD: central composite rotatable design; $\mathrm{RBPC}$ : rice bran protein concentrate; BSA: bovine serum albumin. 
have been applied at different ultrasonic frequencies (FFD-A: $37 \mathrm{kHz}$; and FFD-B: $80 \mathrm{kHz}$ ) to evaluate the effects of four variables on the extraction process, such as: $\mathrm{pH}(8-10)$, temperature $\left(25-45^{\circ} \mathrm{C}\right)$, ultrasonic exposure time (5-30 $\mathrm{min})$, and ultrasonic treatment amplitude (40-100\%). Independent variable, percentage of extracted protein (g of protein $100 \mathrm{~g}^{-1}$ of DRB), have been selected from preliminary tests based on scientific studies (GNANASAMBANDAM \& HELTIARACHCHY, 1995; GUPTA et al., 2008; FAN et al., 2012; ZHANG et al., 2012). Real and coded values of studied FFDs variables are shown in table 1 .

FFD runs have been conducted in accordance with a patented proposed (HYUN-JUN et al., 2009), with some modifications. Extraction procedure started by suspending $30 \mathrm{~g}$ of DRB in 170 $\mathrm{mL}$ of ultrapure water and correcting suspension $\mathrm{pH}$ with $2 \mathrm{~mol} \mathrm{~L}^{-1} \mathrm{NaOH}$ solution, in accordance with proposed design levels. Subsequently, the suspension was disposed in a glass becker and submitted to indirect sonicate in an ultrasonic bath (Elmasonic, $\mathrm{P} 60 \mathrm{H}$, Elma, Germany) at 37 and $80 \mathrm{kHz}$ frequencies, using the temperature, exposure time, and amplitude proposed by the design in table 1 . Temperature was controlled by ultrasound bath heating system itself and cooling by the addition of ice. Phase separation has been done by centrifugation at $11979 \mathrm{~g}$ at $25^{\circ} \mathrm{C}$ for $15 \mathrm{~min}$ (Cientec, CT5000R, Brazil).
FFDs performance allowed the selection of statistically significant variables $(\mathrm{P} \leq 0.05)$ in relation to DRB protein extraction process. Following that, a central composite rotatable design (CCRD) with the variable $\mathrm{pH}(8-10)$ and temperature $\left(15-45^{\circ} \mathrm{C}\right)$, three central point repetitions, and four axis points $\left(2^{2}\right.$, totaling 11 runs) was done. The CCRD $2^{2}$ matrix with real and coded values of studied variables is shown in table 2. Further, the CCRD experiments were validated in the optimized condition for DRB protein extraction.

The supernatants protein contents collected from FFDs and CCRD have been evaluated by MicroKjeldahl method (AOAC, 2005) and a 5.95 nitrogen conversion factor has been used. Protein recovery percentage has been calculated taking into account the supernatants protein obtained from the extraction process and initial protein value on DRB (Equation 1). Proteins content used for calculating the recovery percentage has been described in wet-basis.

$$
\mathrm{R}=\frac{\text { Supernatant protein content }}{\text { DRBP protein content }} \times 100 \%
$$

Obtainment of the rice bran protein concentrate (RBPC)

The protein precipitation stage was carried out after establishing the best extraction condition

Table 1 - FFDs $2^{4-1}$ matrix (FFD-A: $37 \mathrm{kHz}$; FFD-B: $80 \mathrm{kHz}$ ) with coded and real values (in parentheses) of independent and dependent variables for protein extraction from defatted rice bran (DRB).

\begin{tabular}{|c|c|c|c|c|c|c|}
\hline Run & $\mathrm{x} 1$ & $\mathrm{x} 2$ & $\mathrm{x} 3$ & $\mathrm{x} 4$ & FFD-A & FFD-B \\
\hline & & & & & $\mathrm{y} 1^{*}$ & $\mathrm{y} 2^{*}$ \\
\hline 1 & $-1(8)$ & $-1(25)$ & $-1(5)$ & $-1(40)$ & $1.83^{\mathrm{a}} \pm 0.09$ & $1.50^{\mathrm{b}} \pm 0.02$ \\
\hline 2 & $+1(10)$ & $-1(25)$ & $-1(5)$ & $+1(100)$ & $2.09^{\mathrm{a}} \pm 0.03$ & $1.53^{b} \pm 0.07$ \\
\hline 3 & $-1(8)$ & $+1(45)$ & $-1(5)$ & $+1(100)$ & $1.80^{\mathrm{a}} \pm 0.02$ & $1.51^{\mathrm{b}} \pm 0.02$ \\
\hline 4 & +1 (10) & $+1(45)$ & $-1(5)$ & $-1(40)$ & $2.15^{\mathrm{a}} \pm 0.00$ & $1.89^{b} \pm 0.04$ \\
\hline 5 & $-1(8)$ & $-1(25)$ & $+1(30)$ & $+1(100)$ & $1.83^{\mathrm{a}} \pm 0.03$ & $1.70^{b} \pm 0.04$ \\
\hline 6 & $+1(10)$ & $-1(25)$ & $+1(30)$ & $-1(40)$ & $2.14^{\mathrm{a}} \pm 0.01$ & $2.00^{\mathrm{b}} \pm 0.03$ \\
\hline 7 & $-1(8)$ & $+1(45)$ & $+1(30)$ & $-1(40)$ & $1.86^{\mathrm{a}} \pm 0.04$ & $1.69^{b} \pm 0.04$ \\
\hline 8 & $+1(10)$ & $+1(45)$ & $+1(30)$ & $+1(100)$ & $2.52^{\mathrm{a}} \pm 0.09$ & $2.16^{b} \pm 0.03$ \\
\hline 9 & $0(9)$ & $0(35)$ & $0(17.5)$ & $0(70)$ & $2.02^{a} \pm 0.06$ & $1.79^{b} \pm 0.03$ \\
\hline 10 & $0(9)$ & $0(35)$ & $0(17.5)$ & $0(70)$ & $2.12^{\mathrm{a}} \pm 0.03$ & $1.85^{b} \pm 0.03$ \\
\hline 11 & $0(9)$ & $0(35)$ & $0(17.5)$ & $0(70)$ & $2.08^{\mathrm{a}} \pm 0.01$ & $1.75^{b} \pm 0.01$ \\
\hline
\end{tabular}

$\mathrm{x} 1$ : $\mathrm{pH} ; \mathrm{x} 2$ : temperature $\left({ }^{\circ} \mathrm{C}\right) ; \mathrm{x} 3$ : ultrasound exposure time (min); $\mathrm{x} 4$ : ultrasound treatment amplitude (\%); y1: percentage of protein extracted ( $\mathrm{g}$ of protein $100 \mathrm{~g}^{-1}$ of DRB) for $37 \mathrm{kHz}$ frequency; y2: percentage of protein extracted ( $\mathrm{g}$ of protein $100 \mathrm{~g}^{-1}$ of $\mathrm{DRB}$ ) for 80 $\mathrm{kHz}$ frequency; ${ }^{*}$ mean \pm standard error $(\mathrm{n}=3)$; different letters on the same line indicate statistically significant differences by Tukey test $(\mathrm{P} \leq 0.05)$. 
Table 2 - CCRD $2^{2}$ matrix with coded and real values (in parentheses) of independent and dependent variables for protein extraction from defatted rice bran (DRB).

\begin{tabular}{lcccc}
\hline Run & $\mathrm{x} 1$ & $\mathrm{x} 2$ & $\mathrm{y} 1^{*}$ & $\mathrm{y} 2$ \\
\hline 1 & $-1(8.3)$ & $-1(19)$ & $1.91^{\mathrm{d}} \pm 0.05$ & 1.99 \\
2 & $1(9.7)$ & $-1(19)$ & $2.25^{\mathrm{b}} \pm 0.03$ & 2.23 \\
\hline 3 & $-1(8.3)$ & $1(41)$ & $2.05^{\mathrm{c}} \pm 0.01$ & 2.11 \\
\hline 4 & $1(9.7)$ & $1(41)$ & $2.16^{\mathrm{bc}} \pm 0.03$ & 2.35 \\
\hline 5 & $-1.41(8)$ & $0(30)$ & $2.01^{\mathrm{cd}} \pm 0.02$ & 2.00 \\
\hline 6 & $1.41(10)$ & $0(30)$ & $2.37^{\mathrm{a}} \pm 0.01$ & 2.34 \\
\hline 7 & $0(9)$ & $-1.41(15)$ & $2.08^{\mathrm{c}} \pm 0.05$ & 2.08 \\
\hline 8 & $0(9)$ & $1.41(45)$ & $2.37^{\mathrm{a}} \pm 0.01$ & 2.25 \\
\hline 9 & $0(9)$ & $0(30)$ & $2.19^{\mathrm{b}} \pm 0.01$ & 2.17 \\
\hline 10 & $0(9)$ & $0(30)$ & $2.23^{\mathrm{b}} \pm 0.03$ & 2.17 \\
\hline
\end{tabular}

$\mathrm{x} 1: \mathrm{pH} ; \mathrm{x} 2$ : ultrasound exposure time (min); $\mathrm{y} 1$ : percentage of protein extracted ( $\mathrm{g}$ of protein $100 \mathrm{~g}^{-1}$ of DFRB); y2: percentage of protein extracted predicted by the model; ${ }^{*}$ mean \pm standard error $(n=3)$; different letters on the same column indicate statistically significant differences by Tukey test $(\mathrm{P} \leq 0.05)$.

from the sequential strategy of experimental design. The collected supernatants had their $\mathrm{pH}$ adjusted to 4.5 with $3 \mathrm{~mol} \mathrm{~L}^{-1} \mathrm{HCl}$ which is the rice proteins isoelectric point (GUPTA et al., 2008). The solution was left to precipitate overnight at $10^{\circ} \mathrm{C}$, followed by centrifugation at $11979 \mathrm{~g}$ at $25^{\circ} \mathrm{C}$ for $15 \mathrm{~min}$ (Cientec, CT5000R, Brazil). The precipitate was washed three times with purified water and neutralized $(\mathrm{pH} 7.0)$ with $2 \mathrm{~mol} \mathrm{~L}^{-1} \mathrm{NaOH}$. Next, the precipitate was frozen $\left(-18{ }^{\circ} \mathrm{C}\right.$ ) and freeze-dried (Labconco, Free Zone, USA). The drying process was conducted for $24 \mathrm{~h}$ $\left(-40^{\circ} \mathrm{C}, 0.8 \mathrm{mbar}\right)$.

\section{Composition and color}

The centesimal composition (moisture, protein, ash and lipids) of DRB and RBPC were performed according to Association of Official Analytical Chemists (AOAC, 2005). The nitrogen content was determined by micro-Kjeldahl method, using $0.5 \mathrm{~g}$ of DRB or $2 \mathrm{~mL}$ of RBPC supernatant after centrifugation and $10 \mathrm{~mL} \mathrm{H}_{2} \mathrm{SO}_{4}$ in sample digestion performed at $300{ }^{\circ} \mathrm{C}$, followed by neutralization with

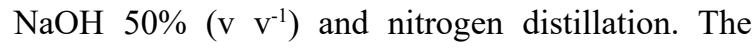
titration was performed with $0.01 \mathrm{~mol} \mathrm{~L}^{-1} \mathrm{H}_{2} \mathrm{SO}_{4}$ and mixed indicator (methyl red and bromocresol green), applying a factor of 5.95 to convert nitrogen to protein. Carbohydrate were quantified by difference. For mineral analysis, the RBPC samples were digested by microwave-assisted wet digestion method using a microwave oven (Multiwave 3000, Anton Paar, Graz, Austria) equipped with eight high-pressure quartz vessels with internal volume of $80 \mathrm{~mL}$. The maximum operational temperature and pressure were set at 280 ${ }^{\circ} \mathrm{C}$ and 80 bar, respectively. A sample mass of 300 $\mathrm{mg}$ of RBPC were directly weighed into the quartz vessels and added of $6 \mathrm{~mL}$ of $14.4 \mathrm{~mol} \mathrm{~L}^{-1} \mathrm{HNO}_{3}$ solution. The following heat steps were used: $15 \mathrm{~min}$ at $1400 \mathrm{~W}$ and holding for $10 \mathrm{~min}$, and $20 \mathrm{~min}$ at $0 \mathrm{~W}$ (cooling step). Obtained digests were transferred to a volumetric flask and the final volume was completed to $25 \mathrm{~mL}$ with ultrapure water.

The trace-elements determination was performed using an inductively coupled plasma mass spectrometer (ICP-MS) (Perkin-Elmer-SCIEX, model Elan DRC II, Thornhill, Canada), equipped with a concentric nebulizer (Meinhard Associates, Golden, USA), a cyclonic spray chamber (Glass Expansion, Inc., West Melbourne, Australia), and a quartz torch and injector tube ( $2 \mathrm{~mm}$ i.d.). Instrumental performance optimization, including nebulizer gas, flow rate, ion lens voltage and torch alignment, was carried out following the instructions of the manufacturer. The following operational conditions were used: radiofrequency power of 1400 $\mathrm{W}$, plasma gas flow rate of $15 \mathrm{~L} \mathrm{~min}^{-1}$, auxiliary gas flow rate of $1.20 \mathrm{~L} \mathrm{~min}^{-1}$ and nebulizer gas flow rate of $1.08 \mathrm{~L} \mathrm{~min}^{-1}$. Isotopes monitored were ${ }^{75} \mathrm{As},{ }^{112} \mathrm{Cd}$, ${ }^{59} \mathrm{Co},{ }^{52} \mathrm{Cr},{ }^{65} \mathrm{Cu},{ }^{55} \mathrm{Mn},{ }^{98} \mathrm{Mo},{ }^{58} \mathrm{Ni},{ }^{208} \mathrm{~Pb},{ }^{121} \mathrm{Sb},{ }^{82} \mathrm{Se}$, ${ }^{120} \mathrm{Sn},{ }^{88} \mathrm{Sr}$ and ${ }^{64} \mathrm{Zn}$.

The RBPC amino acids profile and the protein nitrogen were evaluated using ultra violet high performance liquid chromatography (HPLC-DAD/ 
UV) with reverse phase column. For each essential amino acid from RBPC was evaluated a chemical score, which can be calculated by Equation 2. The reference protein used was in accordance to $\mathrm{WHO} /$ FAO/UNU (WHO/FAO/UNU, 1981, 2007).

Chemical score $=\frac{\mathrm{g} \text { amino acid } .100 \mathrm{~g} \text { test protein }^{-1}}{{\mathrm{~g} \text { same amino acid } .100 \mathrm{~g}^{-1} \text { refence protein }}^{-1}}$

RBPC surface color was measured using a Minolta Chromameter CR-400 (Osaka, Japan) with a specular component, a D illuminant and a $45^{\circ}$ observer. Color results were expressed in the CIELAB (Commission International for Illumination) dimensions of lightness $\left(L^{*}\right)$, redness $\left(a^{*}\right)$ and yellowness $\left(b^{*}\right)$.

\section{Functional properties}

The functional properties were determined according to MENEGOTTO (2019), with modifications. For solubility, the RBPC $(0.2 \mathrm{~g})$ was mixed with $40 \mathrm{~mL}$ of water and magnetically stirred (Fisatom, 752A, São Paulo, Brazil) for $10 \mathrm{~min}$ at room temperature $\left(30{ }^{\circ} \mathrm{C}\right)$. The $\mathrm{pH}$ suspension was adjusted to $2,3,4,5,6,7,8,9$ e 10 by addition of $2.0 \mathrm{~mol} \mathrm{~L}^{-1} \mathrm{HCl}$ or $2.0 \mathrm{~mol} \mathrm{~L}^{-1} \mathrm{NaOH}$. Subsequently, the samples were transferred in a $50 \mathrm{~mL}$ falcon tubes and centrifuged (Rotina $420 \mathrm{R}$, Hettich Zentrifugen, Germany) at $10000 \mathrm{~g}$ at $25{ }^{\circ} \mathrm{C}$ for $15 \mathrm{~min}$. The supernatant was used to quantify the soluble protein content by LOWRY et al. (1951) method; the samples absorbance were measured using a spectrophotometer (UV-Vis Lambda XLS HP9 2FX, PerkinElmer, USA) at $660 \mathrm{~nm}$ wavelength. According to the same conditions, without $\mathrm{pH}$ adjusts and centrifugation, a control sample was performed. The results were calculated according Equation 3 and expressed as a percentage of soluble protein.

Protein solubility $(\%)=\frac{\text { supernatant soluble protein }\left(\mathrm{g} \mathrm{L}^{-1}\right)}{\text { control sample soluble protein }\left(\mathrm{g} \mathrm{L}^{-1}\right)} \times 100$

For water absorption capacity (WAC) and oil absorption capacity (OAC) the RBPC $(0.1 \mathrm{~g})$ was added to distillated water or corn oil, respectively, up to $5.0 \mathrm{~mL}$ in a $15 \mathrm{~mL}$ falcon tube, and vortex stirred (IKA, Staufen, Germany) at a temperature of $30{ }^{\circ} \mathrm{C}$ for $1 \mathrm{~min}$. The mixture was submitted to rest for $30 \mathrm{~min}$, and then centrifuged (Cientec, CT $5000 \mathrm{R}$, São Paul, Brazil) at $3000 \mathrm{~g}$ at $25^{\circ} \mathrm{C}$ for $15 \mathrm{~min}$. The supernatant was carefully drained on a clock glass for $25 \mathrm{~min}$, thus just the water or the oil absorbed by proteins were measured by the weight. The results were expressed as $g$ of water or oil held per $g$ of RBPC and calculated by Equation 4 and 5 .

WAC $\left(\mathrm{g} \cdot \mathrm{g}^{-1}\right)=\frac{\text { water held }(\mathrm{g})}{\mathrm{RBPC} \text { initial weight }(\mathrm{g})} \times 100$
OAC $\left(\mathrm{g} \cdot \mathrm{g}^{-1}\right)=\frac{\text { oil held }(\mathrm{g})}{\text { RBPC initiăl weight }(\mathrm{g})} \times 100$

The foaming capacity and stability of RBPC experiments were conducted on $50 \mathrm{~mL}$ falcon tubes and the dilutions were prepared with $0.02 \mathrm{~g}$ of RBPC and $5.0 \mathrm{~mL}$ of sodium phosphate buffer $(0.01$ mol L-1) on $\mathrm{pH} 4,6$ e 8 . The samples were submitted to agitation (Fisatom, 952, n.12171, São Paulo, Brazil) for $10 \mathrm{~min}$, and stirred for $1 \mathrm{~min}$ on a mixer with spiral beater (Britânia, BMM2, China). Thus, the increases of foam volumes by the stirred were evaluated and foaming capacity could be calculated by Equation 6 . The foaming stability was determined considering the foam produced in foaming capacity test, which was left to rest for $30 \mathrm{~min}$ at room temperature $\left(30^{\circ} \mathrm{C}\right)$ and the final volume was measured, allowing the foaming stability calculation by Equation 7 .

Foaming capacity $(\%)=\frac{\text { final suspension volume }(\mathrm{mL})}{\text { initial suspension volume }(\mathrm{mL})} \times 100$

Foaming stability $(\%)=\frac{\text { foam volume after } 30 \mathrm{~min}(\mathrm{~mL})}{\text { initial suspension volume }(\mathrm{mL})} \times 100($

The emulsifying capacity was conducted on $50 \mathrm{~mL}$ beaker and the dilutions were prepared with $0.04 \mathrm{~g}$ of RBPC and $10 \mathrm{~mL}$ of sodium phosphate buffer $\left(0.01 \mathrm{~mol} \mathrm{~L}^{-1}\right)$ on $\mathrm{pH} \mathrm{2,} \mathrm{4,6} \mathrm{e} \mathrm{8.} \mathrm{After,} \mathrm{the}$ suspension was stirred for 5 min (Fisatom, 952, São Paulo, Brazil) and the emulsifying occurred by the slow addition of corn oil droplets $(2 \mathrm{~mL})$ and under continuous agitation. The emulsion point was visually verified by the formation of a homogeneous phase (cream). The obtained emulsion was transferred to a $50 \mathrm{~mL}$ falcon tube and centrifuged (Cientec, CT 5000 R, São Paulo, Brazil) at $2087 \mathrm{~g}$ for $5 \mathrm{~min}$. The emulsifying capacity was expressed based on Equation 8. A similar procedure was followed to determine the emulsifying stability, but after the emulsion formation the samples were incubated at $80{ }^{\circ} \mathrm{C}$ for $30 \mathrm{~min}$, before the centrifugation. The emulsifying stability was calculated according to Equation 9.

With the purpose to compare the results obtained to RBPC, dried bovine serum albumin (BSA) was also evaluated according to the same conditions for WAC, OAC, foaming and emulsifying properties.

Emulsifying capacity $(\%)=\frac{\text { volume of the emulsifier layer }(\mathrm{mL})}{\text { emulsion initial volume }(\mathrm{mL})} \times 100(8)$

Emulsifying stability $(\%)=\frac{\text { volume of the emulsifier layer }(\mathrm{mL})}{\text { emulsion initial volume }(\mathrm{mL})} \times 100$ 


\section{Statistical analysis}

FFDs and CCRD runs were conducted randomly, and the data were analysed by Experimental Design procedure of Statistica 8.0 software (Statsoft Inc., Tulsa, USA). The adequacy of the models was expressed by the determination coefficient (R2), adjusted R2 (R2-adj) and statistical significance was determined by analysis of variance (Anova) $(\mathrm{P} \leq$ 0.05 ). Tukey's test has been used in order to evaluate statistically significant differences in the average $(\mathrm{P}$ $\leq 0.05$ ). Results in triplicate were expressed as the mean \pm standard error.

\section{RESULTS AND DISCUSSION}

\section{Selection of variables for DRB protein extraction improvement}

In the present study, ultrasonic-assisted extraction in an alkaline medium was used in DRB proteins extraction $(14.89 \pm 0.29 \%$ of proteins in wet basis) and results were presented in table 1 . The protein extraction percentages observed for FFD-A (37 kHz) were higher (from $1.80 \%$ to $2.52 \%$ ) if compared with the respective run in FFD-B at $80 \mathrm{kHz}$ frequency (from $1.50 \%$ to $2.16 \%)(\mathrm{P} \leq 0.05)$. The process allows protein recovery percentages $(\mathrm{R})$ from $14.89 \%$ to $16.93 \%$ for $37 \mathrm{kHz}$ frequency, and between $10.35 \%$ and $14.51 \%$ for $80 \mathrm{kHz}$ frequency. Thus, the protein content extracted at $37 \mathrm{kHz}$ frequency was significantly higher than $80 \mathrm{kHz}(\mathrm{P} \leq 0.05$, Tukey test $)$ for all runs, evidenced by the higher soluble protein content and higher protein recovery. Such difference is related to the fact that cavitation is greater at lower frequencies and that bubbles generated during cavitation are relatively large, making their collapse to result in strong shock waves, useful in mechanical cut applications (CHEMAT et al., 2011). Cavitation bubbles formation is more difficult at higher frequencies; however, such bubbles formation can occur by virtue of shorter rarefaction cycles due to time, temperature, and collapsing pressure, being mutually dependent of these factors. However, ultrasonic intensity cannot be increased indefinitely, as bubbles could grow so much in rarefaction that the time available for collapse becomes inadequate. In this way, it was opted to study only the $37 \mathrm{kHz}$ frequency interference for the CCRD development.

Ultrasonic exposure time and $\mathrm{pH}$ were the variables with the effects $(\mathrm{P} \leq 0.05)$ on the extraction process (Table 3 ). The $\mathrm{pH}$ positively influenced the protein extraction in both FFD-A and FFD-B, indicating that the highest percentage of proteins extraction occurs at higher $\mathrm{pH}$ levels within the studied range (8 to 10 ). Normally, protein extraction from vegetables involves alkaline extraction, in which proteins are more negatively charged and repulsion is greater among molecules, increasing proteins solubility, consequently facilitating its extraction.

The temperature had no effect $(\mathrm{P}>0.05)$ on the response evaluated in both FFDs, indicating that the temperature studied range $\left(25-45^{\circ} \mathrm{C}\right)$ presented similar effects on the DRB proteins extraction. KARKI et al. (2010) observed that soy protein extraction was not affected $(\mathrm{P}>0.05)$ by temperature fluctuation during sonication $\left(29-38{ }^{\circ} \mathrm{C}\right)$ in an ultrasonic bath with $\mathrm{pH} 8.5,20 \mathrm{kHz}$ frequency, and $1280 \mathrm{~W}$ power; protein extraction did not increase by thermal effects but by cellular rupture and particles size reduction. High-temperature protein extraction processes could be unfavorable as they induce protein denaturation, resulting in low-quality proteins (DAMODARAN, 2010). Therefore, this variable was fixed at $30{ }^{\circ} \mathrm{C}$,

Table 3 - Effects of FFDs $2^{4-1}$ factors on percentage of proteins extracted from defatted rice bran (DRB) (g protein $\left.100 \mathrm{~g}^{-1} \mathrm{DRB}\right)$.

\begin{tabular}{|c|c|c|c|c|c|c|c|c|}
\hline \multirow[t]{2}{*}{ Factor } & \multicolumn{5}{|c|}{-----------FFD-A: 37 kHz ultrasound frequency----------- } & \multicolumn{3}{|c|}{-------FFD-B: 80 kHz ultrasound frequency----- } \\
\hline & Effect & Standard error & $\mathrm{t}(6)$ & $\mathrm{p}$ - value & Effect & Standard error & $\mathrm{t}(6)$ & $\mathrm{p}$ - value \\
\hline Mean & 2.04 & 0.03 & 64.86 & $0.0000^{*}$ & 2.17 & 0.02 & 115.48 & $0.0000^{*}$ \\
\hline $\mathrm{x} 1$ & 0.39 & 0.07 & 5.34 & $0.0018^{*}$ & 0.28 & 0.04 & 6.34 & $0.0007^{*}$ \\
\hline $\mathrm{x} 2$ & 0.11 & 0.07 & 1.50 & 0.1852 & 0.03 & 0.04 & 0.75 & 0.4802 \\
\hline $\mathrm{x} 3$ & 0.12 & 0.07 & 1.67 & 0.1464 & 0.12 & 0.04 & 2.69 & $0.0362^{*}$ \\
\hline $\mathrm{x} 4$ & 0.07 & 0.07 & 0.90 & 0.4038 & 0.04 & 0.04 & 0.97 & 0.3706 \\
\hline
\end{tabular}

$\mathrm{x} 1$ : $\mathrm{pH} ; \mathrm{x} 2$ : temperature $\left({ }^{\circ} \mathrm{C}\right) ; \mathrm{x} 3$ : ultrasound exposure time $(\mathrm{min}) ; \mathrm{x} 4$ : amplitude $(\%)$; FFD-A: $\mathrm{R}^{2}=85.15 \%$ and $\mathrm{R}^{2}$ adjusted $=75.24 \%$;

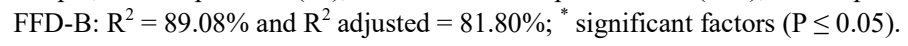


more economically viable due to its easy control, because is near the room temperature.

Ultrasonic exposure time presented a significant effect only for the $80 \mathrm{kHz}$-frequency extraction. The response was positively influenced $(\mathrm{P} \leq 0.05)$ within the studied range $(5-30 \mathrm{~min})$, thus and increase in ultrasound exposure time increased the protein extraction. Ultrasonic exposure time on puerarin extraction efficiency from Radix Puerariae Lobatae - used in China as an antipyretic and antiemetic agent - was evaluated at $40 \mathrm{kHz}$ frequency, at periods of 15, 20,30, 40, and $50 \mathrm{~min}$, and an increase in extraction was observed in ultrasonic exposure time of $30 \mathrm{~min}$ (FAN et al., 2012). Other studies indicated that a greater time exposure to ultrasonic waves could contribute towards greater extraction percentages of desired compounds (ZHAO et al., 2013). Therefore, this variable level was rearranged for further design in order to achieve a higher protein extraction.

The ultrasonic treatment amplitude had no significant effect $(\mathrm{P}>0.05)$ in the evaluated response for both FFDs within the range studied (40$100 \%)$. However, the observed effects were positive, confirming the statements of several authors, who have indicated that by increasing the amplitude intensity, the sonochemical effects are deeper (FILGUEIRAS et al., 2000), benefiting extraction of the desired compounds. So, as the maximum amplitude level for the ultrasonic bath used in this study was $100 \%$, it was fixed at this level for the next design (CCRD).

\section{Optimization of protein extraction from $D R B$}

In order to optimize the protein extraction from DRB, a CCRD $2^{2}$ (3 central points, totaling 11 runs) was performed considering the variables with effects obtained in FFDs. The frequency of 37 $\mathrm{kHz}$, temperature of $30{ }^{\circ} \mathrm{C}$, and amplitude of $100 \%$ were fixed and the $\mathrm{pH}$ and ultrasonic exposure time were varied from 8 to 10 and from 15 to $45 \mathrm{~min}$, respectively. The matrix with the real and coded values of the studied variables and the response are shown in table 2 . The extraction percentages varied from $1.91 \%$ to $2.37 \%$, allowing protein recovery between $12.83 \%$ and $15.92 \%$. The higher protein extraction was observed in runs with higher $\mathrm{pH}$ values, especially above 9 .

CCRD results analysis enable to obtain the regression coefficients for the protein extraction considering the variables studied. The coefficient of linear $\mathrm{pH}$ was the variable with higher and significant effect $(\mathrm{P} \leq 0.05)$ in protein extraction. Non-significant effects were incorporated into the residue of the model. A valid linear model was obtained ( $p$-value
$=0.0095)$ and the variation percentage explained by the model was adequate $\left(\mathrm{R}^{2}=68 \%\right.$; adjusted $\mathrm{R}^{2}=60 \%$ ). The model was considered adjusted to the experimental data, allowing response surface generation (Figure 2). Moreover, the predicted values (Table 2) presented relative deviations lower than $10 \%$, confirming the model's adequate adjustment to the experimental data.

It was possible to observe, through response surface (Figure 2), that $\mathrm{pH}$ was the variable with the greatest influence on protein extraction process, and $\mathrm{pH}$ values close to 10 allowed a greater extraction percentage. For ultrasonic exposure time variable was noticed that periods of time between 30 and 45 min presented better results.

Thus, the optimized conditions for DRB protein extraction was validated. The following conditions were employed: frequency of $37 \mathrm{kHz}$; temperature of $30{ }^{\circ} \mathrm{C}$; ultrasound amplitude of $100 \%$; $\mathrm{pH}$ of 10; ultrasound exposure time of $30 \mathrm{~min}$. The validation runs were similar than obtained in run 6 of CCRD ( $P>0.05$ ), allowing $2.24 \% \pm 0.04$ of protein extraction, reaching a $15.07 \%$ of final protein recovery in relation to the initial protein percentage of DRB. Results obtained in the present study were considered higher than reported by PHONGTHAI et al. (2016a), which reached $4.73 \%$ of extracted protein from DRB at $76 \%$ amplitude, 18 min ultrasonic exposure time, and a DRB: water ratio of $0.99 \mathrm{~g}$ : $10 \mathrm{~mL}$. The same group of researchers employing microwave for protein extraction from DRB and achieved a $4.37 \%$ of extraction (PHONGTHAI et al., 2016b), showing that ultrasound are more efficient technique for DRB proteins extraction.

There are only a few results obtained from studies describing DRB protein extraction processes if compared to other sources of protein that are raw material for concentrates preparation and protein isolate (whey and egg white proteins). However, taking into account that DRB is a by-product from rice processing industry, often either discarded or used as animal feed, the study for DRB proteins extraction and recovery is imperative for the industrial byproduct use. Ultrasound technology contributes to improve the results of protein extraction from rice bran due to the phenomenon of cavitation, which causes the rupture of cells and the transfer of mass to the medium. This cellular breakdown is very desirable in the extraction of substances from a given medium (CHEMAT et al., 2011).

Alkaline solutions have been widely used as an efficient and useful method of proteins extraction from vegetable sources. Vegetable proteins are hardly 


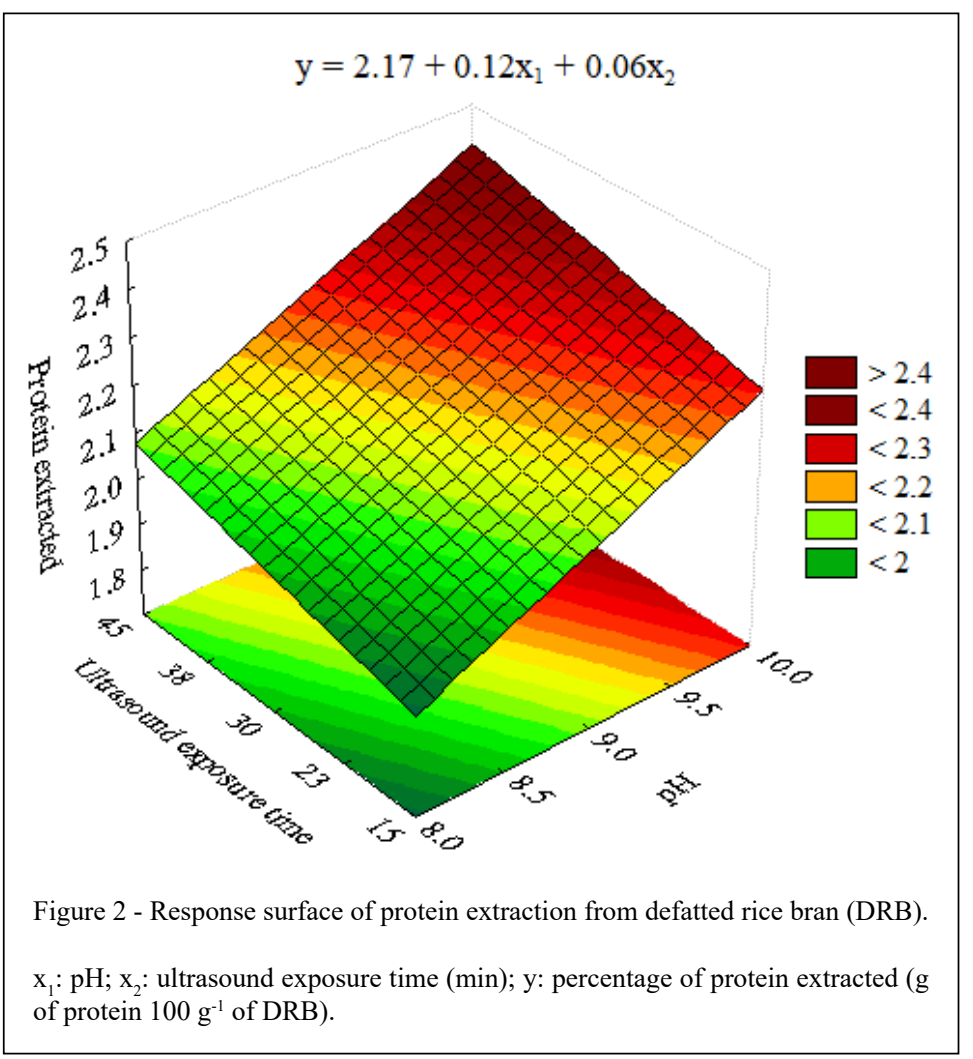

water-soluble due to their hydrophobic nature and the presence of disulphide bond among protein molecules. With alkalinization of the medium by $\mathrm{NaOH}$ addition, disulphide bonds breakdown occurs causing structural changes and an increase in proteins molecules superficial charge, making proteins more soluble (SHEN et al., 2008; DAMODARAN, 2010). In addition, the ultrasound could improve compounds extraction from a tissue due the mechanical effects and greater penetration of solvent, improving the mass transfer (CHEMAT et al., 2011).

\section{RBPC composition and color}

The DRB centesimal composition evaluated in this study are present in table 4 and the results are in the range described by Romero (ROMERO, 2015). However, results obtained of RBPC composition presented higher content of protein and lipid and lower content of carbohydrate in comparison with YADAV et al. (2011); the differences in RBPC composition may be justified by the different strategy used on the extraction step: ultrasound waves at $\mathrm{pH} 10$ and $30{ }^{\circ} \mathrm{C}$ for 30 min (current study) versus $\mathrm{pH} 11$ at $60{ }^{\circ} \mathrm{C}$ for 60 min (YADAV; YADAV; CHAUDHARY, 2011).
Moreover, other studies used sonication on DRB protein extraction and obtained a RBPC with a lower protein content (72.06 and 76.09\%) (CHITTAPALO \& NOOMHORM, 2009; LY et al., 2018). The greater protein content obtained in the current study can be attributed to the sequential strategy of the experimental design applied as a tool to optimize the protein extraction process.

Regarding the mineral composition, Mn was the predominant mineral on RBPC, followed by $\mathrm{Cu}, \mathrm{Zn}, \mathrm{As}, \mathrm{Ni}, \mathrm{Mo}, \mathrm{Sr}, \mathrm{Co}, \mathrm{Pb}$ and $\mathrm{Cr} ; \mathrm{Sb}$, Se and $\mathrm{Sn}$ were not detected (Table 5). In general, the mineral composition of plants may be easily influenced and controlled by their genetics, soil fertility and the environment (MILLER, 2010). However, even submitted through ultrasound and alkali treatment, the RBPC has a considerable amount of ash, which corresponded to minerals with effects on the human body. The RBPC is characterized as a light brown fine powder, with a velvety texture. In contrast, RBPC extracted in alkaline medium ( $\mathrm{pH} 11$ ) with ultrasound waves $(100 \mathrm{~W}, 5 \mathrm{~min})$ generates a darker product $\left(L^{*}: 46.17\right)$ (Table 5), probably associated with the extraction procedure employed (CHITTAPALO \& NOOMHORM, 2009).

Ciência Rural, v.50, n.12, 2020. 
Table 4 - Centesimal composition of defatted rice bran (DRB) and rice bran protein concentrate (RBPC).

\begin{tabular}{|c|c|c|}
\hline Parameters & DRB & $\mathrm{RBPC}$ \\
\hline \multicolumn{3}{|c|}{-------Centesimal composition (g $100 \mathrm{~g}^{-1}$; dry basis)------- } \\
\hline Protein & $16.75 \pm 0.29$ & $84.76 \pm 0.29$ \\
\hline Lipids & $1.88 \pm 0.04$ & $9.40 \pm 0.38$ \\
\hline Carbohydrate & 68.65 & ND \\
\hline Ash & $12.72 \pm 0.64$ & $5.71 \pm 0.37$ \\
\hline
\end{tabular}

ND: not detected.

The amino acid profile of RBPC was shown in table 6 and compared with other RBPC, and BSA profiles available in the literature. Subsequently the RBPC amino acid profile was compared to the FAO protein requirement (preschool children 2-5 years), obtaining the essential amino acid chemical score. All essential amino acids content of RBPC are below the standard protein composition (WHO/FAO/ UNU, 1981, 2007); thus, a chemical scores of amino acids $\leq 1.0$ are obtained. It is common in proteins obtained from a low biological value sources, as cereals including rice. Leucine is the RBPC limiting amino acid (chemical score 0.38), followed by lisine $(0.48)$; in contrast, threonine had the highest chemical score (1.0). Other studies evaluated the amino acids profile of RBPC showing some variations, probably, due to the protein extraction procedure employed (TANG et al., 2003; HAN et al., 2015). Comparing the RBPC amino acids profile with BSA, lower amino acids content was observed for RBPC, an expected condition, since the BSA is a protein of high biological value (PRATA \& SGARBIERI, 2008).

Although, non-essential amino acids were detected in the sample, this finding is not relevant, as it is known that these can be produced by the human body from essential amino acids. Protein quality is related to true nitrogen and amino acid retention, which is mainly related to the capacity of the protein to essential amino acids (LEE et al., 2016).

\section{RBPC functional properties}

The results of functional properties are shown in figure 3. The RBPC protein solubility presented a U-shaped trend, with a minimum solubility $(22.2 \%)$ at $\mathrm{pH} 4$, corresponding to the $\mathrm{pI}$ of rice bran proteins as previously demonstrated (GUPTA et al., 2008; ZHANG et al., 2012). In contrast, the RBPC showed great solubility at $\mathrm{pH}$
Table 5 - Mineral composition and color characteristics of rice bran protein concentrate (RBPC).

\begin{tabular}{|c|c|}
\hline Parameters & RBPC \\
\hline \multicolumn{2}{|c|}{-------------Mineral composition $\left(\mu \mathrm{g} \mathrm{g}^{-1} ;\right.$ dry basis)------------- } \\
\hline $\mathrm{Mg}$ & $34.4 \pm 2.78$ \\
\hline $\mathrm{Cu}$ & $25.5 \pm 1.85$ \\
\hline $\mathrm{Zn}$ & $13 \pm 0.44$ \\
\hline As & $2.7 \pm 0.24$ \\
\hline $\mathrm{Ni}$ & $2.4 \pm 0.10$ \\
\hline Mo & $1.96 \pm 0.09$ \\
\hline $\mathrm{Sr}$ & $1.5 \pm 1.11$ \\
\hline Co & $0.95 \pm 0.06$ \\
\hline $\mathrm{Pb}$ & $0.46 \pm 0.02$ \\
\hline $\mathrm{Cr}$ & $0.32 \pm 0.02$ \\
\hline $\mathrm{Sb}$ & ND \\
\hline Se & ND \\
\hline $\mathrm{Sn}$ & ND \\
\hline \multicolumn{2}{|c|}{ 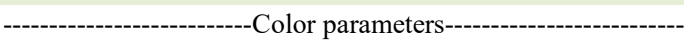 } \\
\hline $\mathrm{L}^{*}$ & $60.42 \pm 2.15$ \\
\hline$a^{*}$ & $-1.31 \pm 0.53$ \\
\hline$b^{*}$ & $20.29 \pm 1.39$ \\
\hline
\end{tabular}

ND: not detected.

$6,7,8,9$ and 10, with no significant difference $(\mathrm{P}>$ $0.05)$; the maximum solubility was $99.7 \%(\mathrm{pH} 7)$. It is recognized that in the $\mathrm{pI}$ the protein solubility is minimum, due to the lack of electrostatic repulsion, which promotes aggregation and precipitation through to the hydrophobic interactions. However at $\mathrm{pH}$ values above or below $\mathrm{pI}$, proteins have positive and negative charges, which allows the electrostatic repulsion and the hydration of charged residues improving the protein solubility, an essential characteristic that may affect the other functional properties (DAMODARAN, 2010).

The RBPC presented higher results for $\mathrm{WAC}$ and $\mathrm{OAC}$ than BSA $(\mathrm{P} \leq 0.05)$. The results obtained in the present study for WAC was lower and, for OAC was higher than values of RBPC extracted by agitation $\left(1 \mathrm{~h}\right.$ ) at $25^{\circ} \mathrm{C}$ in $\mathrm{pH} 9.0$ (WAC: 3.87 to $5.60 \mathrm{~g} \mathrm{~g}^{-1}$; and OAC: 3.74 to $9.18 \mathrm{~g} \mathrm{~g}^{-1}$ ) (CHANDI \& SOGI, 2007). The differences may be associated with the protein extraction procedure, that can be able to improve some functional properties of protein (JAMBRAK et al., 2008). Ultrasound treatment may affect WAC and OAC properties since ultrasonic waves may form free radicals 
Table 6 - Rice bran protein concentrate (RBPC) amino acids profile (mg g protein ${ }^{-1}$ ) obtained in the current and other scientific study and bovine serum albumin (BSA), essential amino acid requirements of preschool children, and amino acid chemical scores of RBPC.

\begin{tabular}{|c|c|c|c|c|c|c|c|}
\hline Amino acid & $\begin{array}{c}\text { RBPC } \\
\text { (current study) }\end{array}$ & $\mathrm{RBPC} \dagger$ & RBPC & BSA $\S$ & \multicolumn{2}{|c|}{$\begin{array}{l}\text { Requirements of } \\
\text { preschool children }\end{array}$} & $\begin{array}{l}\text { RBPC amino acid } \\
\text { chemical score }\end{array}$ \\
\hline Leucine (Leu) & 28 & 79 & 77 & 120 & - & $73^{*}$ & 0.38 \\
\hline Lysine (Lys) & 25 & 52 & 46 & 127 & $52 \partial$ & $64^{*}$ & 0.48 \\
\hline Threonine (Thr) & 27 & 37 & 37 & 58 & $27 \partial$ & $37^{*}$ & 1.00 \\
\hline Phenylalanine (Phe) & 17 & 50 & $82 \mathrm{f}$ & 69 & - & $69^{*} \int$ & $0.43 \int$ \\
\hline Tyrosine (Tyr) & 13 & 38 & $82 f$ & 50 & - & $69^{*} \int$ & - \\
\hline Valine (Val) & 23 & 69 & 55 & 58 & - & $43^{*}$ & 0.53 \\
\hline Histidine (His) & 16 & 31 & 45 & 39 & - & - & - \\
\hline Isoleucine (Ile) & 13 & 45 & 36 & 26 & - & $31^{*}$ & 0.42 \\
\hline Methionine (Met) & 8.0 & - & $27 \neq$ & 8 & $26 \partial \neq$ & $27^{*}$ & $0.77 \neq$ \\
\hline Cysteine (Cys) & 12 & - & $27 \neq$ & 48 & - & $27^{*}$ & 0.44 \\
\hline Tryptophan (Trp) & - & - & 12 & 6 & $7.4 \partial$ & $14^{*}$ & - \\
\hline \multicolumn{8}{|c|}{ 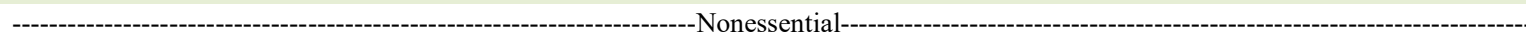 } \\
\hline Glutamic acid (Glu) & 88 & 176 & - & 178 & - & - & - \\
\hline Arginine (Arg) & 56 & 98 & - & 55 & - & - & - \\
\hline Aspartic acid (Asp) & 41 & 109 & - & 119 & - & - & - \\
\hline Glycine (Gly) & 28 & 58 & - & 23 & - & - & - \\
\hline Serine (Ser) & 23 & 45 & - & 46 & - & - & - \\
\hline Proline (Pro) & 15 & - & - & 49 & - & - & - \\
\hline Alanine (Ala) & 30 & 71 & - & 62 & - & - & - \\
\hline
\end{tabular}

$\dagger$ TANG et al. 2003; † HAN, CHEE, and CHO (2015); § PRATA and SGARBIERI (2008); $\partial$ WHO/FAO/UNU (2007); * WHO/FAO/UNU (1981); $\int$ Phe + Tyr; $\neq$ Met + Cys.

that increase WAC (HU et al., 2013); furthermore, ultrasonic waves may increase the protein nonpolar groups exposure, favoring its connection with fat or oil polar fractions, improving OAC (LIN; HUMBERT; SOSULSKI, 1974). It is important to emphasize that greater values of WAC and OAC are considered positive, especially in processed foods, improving water and oil retention in the matrix and obtaining a food product with desired sensory characteristics.

The obtained RBPC had lower values for foaming capacity and stability than BSA $(\mathrm{P} \leq$ 0.05 ) and both proteins, RBPC and BSA, have their foaming properties influenced by $\mathrm{pH}$ as previously reported in the literature (ROMERO, 2015). The lower RBPC foaming capacity and stability is probably associated with the high lipid content, which influenced foaming stability in negative way because the lipids are quickly adsorbed in airwater interface, impeded the protein adsorption
(DAMODARAN, 2010; CANO-MEDINA et al., 2011). The RBPC emulsifying capacity was comparable to BSA in the pHs evaluated $(\mathrm{P}>0.05)$, and both proteins present lower emulsion capacity in the $\mathrm{pH} 2(\mathrm{P} \leq 0.05)$. However, the RBPC present lower emulsifying stability than BSA $(\mathrm{P} \leq 0.05)$, with the greater emulsifying stability observed at $\mathrm{pH}$ 4,6 , and 8 . Although, the emulsifying properties are lower than BSA, they are still considered suitable and in the range described for concentrates obtained from DRB (PHONGTHAI et al., 2016a).

The RBPC functional propertied of solubility, OAC, emulsion capacity and stability are a desirable characteristics in emulsified foods, especially at a neutral or slight acid $\mathrm{pH}$. Furthermore, the RBPC potential use must be considered due to it be a highly available byproduct and because it may be combined with other proteins to improve its functional properties and amino acid biological value. 

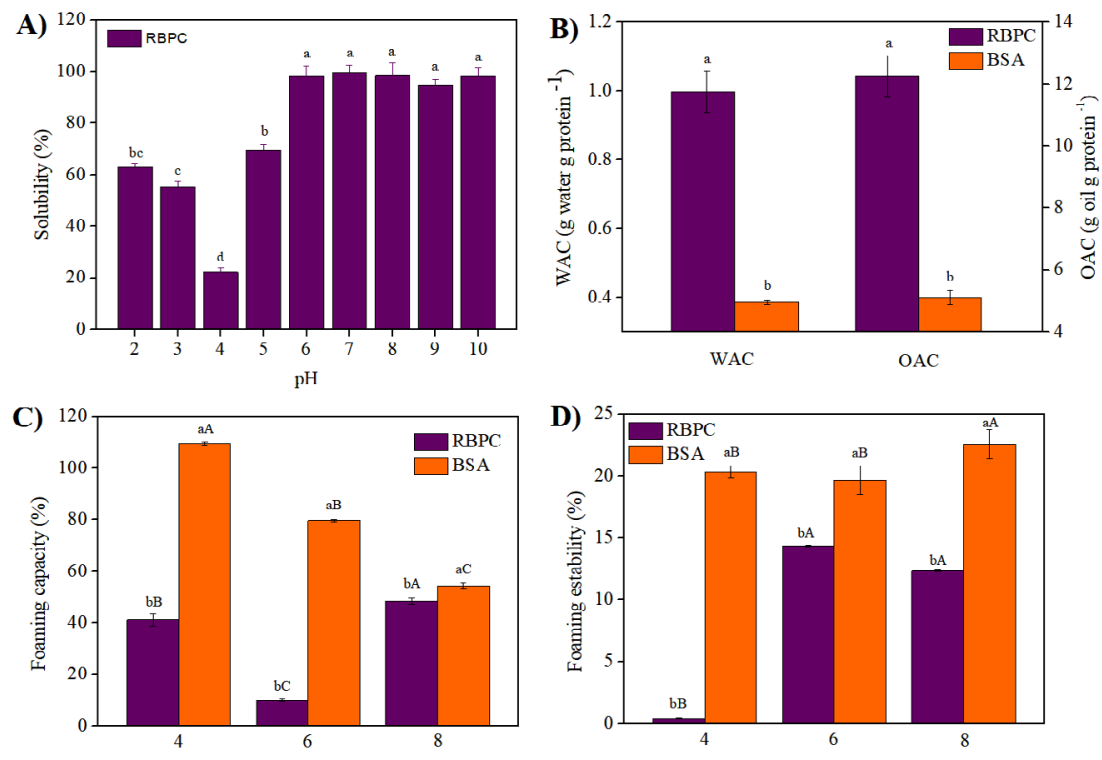

$\mathrm{pH}$

$\mathrm{pH}$
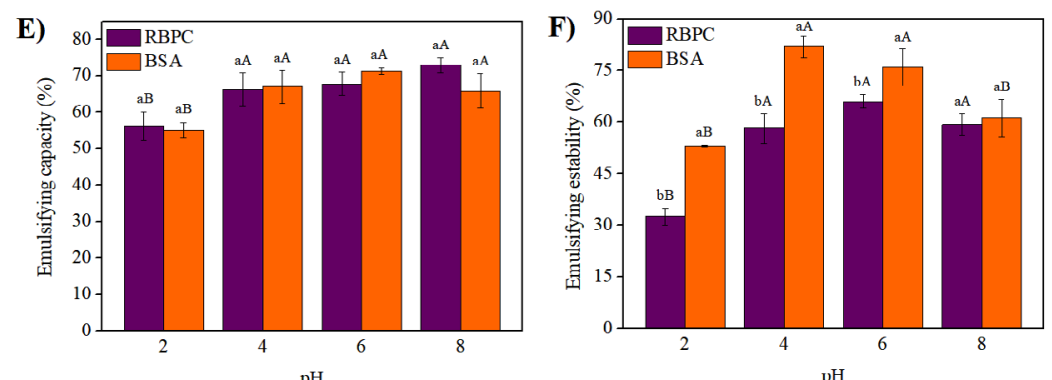

Figure 3 - Functional properties of rice bran protein concentrate (RBPC) and bovine serum albumin (BSA).

Results are expressed by mean \pm standard error $(n=3)$; different lowercase letters indicate statistically significant differences by Tukey test between samples in the same condition $(\mathrm{P} \leq 0.05)$; different uppercase letters indicate statistically significant differences by Tukey test between $\mathrm{pH}$ for the same sample $(\mathrm{P} \leq 0.05)$.

\section{CONCLUSION}

DRB protein extraction contributed to add value to rice bran and the use of a combination of ultrasound exposure in alkaline medium can improve this process. The sequential strategy of experimental design allowed to reach $15.07 \%$ of protein recovery

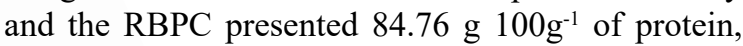
higher values than all reported in the literature. The optimized and validations conditions were: frequency of $37 \mathrm{kHz}$; temperature of $30{ }^{\circ} \mathrm{C}$; ultrasound amplitude of $100 \%$; pH of 10 ; ultrasound exposure time of $30 \mathrm{~min}$. The extraction using ultrasonic waves ensure a suitable RBPC functional property, especially the solubility in $\mathrm{pH}$ above 6 , oil absorption and emulsifying properties. The RBPC presented excellent potential as alternative protein source and food supplement, evidenced from its amino acids and mineral profile. Thus, RBPC can be considered an important food ingredient that can improve the quality of food products contributing with the development of novel foods.

\section{ACKNOWLEDGEMENTS}

This study was financed in part by the Coordenação de Aperfeiçoamento de Pessoal de Nível Superior - Brasil (CAPES), Brasil - Finance Code 001, Conselho Nacional de Desenvolvimento Científico e Tecnológico $(\mathrm{CNPq})$, Fundação Araucária and Universidade Tecnológica Federal do Paraná (UTFPR). 


\section{DECLARATION OF CONFLICT OF INTERESTS}

The authors declare no conflict of interest. The founding sponsors had no role in the design of the study; in the collection, analyses, or interpretation of data; in the writing of the manuscript, and in the decision to publish the results.

\section{AUTHORS' CONTRIBUTIONS}

All authors contributed equally for the conception and writing of the manuscript. All authors critically revised the manuscript and approved of the final version.

\section{REFERENCES}

AOAC. Official methods of analysis of the Association of Official Analytical Chemists. 18. ed. Arlington: AOAC, 2005.

CANO-MEDINA, A. et al. Emulsifying and foaming capacity and emulsion and foam stability of sesame protein concentrates. Food Research International, v.44, n.3, p.684-692, 2011. Available from: <https://www.sciencedirect.com/science/article/abs/pii/ S0963996910004850>. Accessed: Aug. 11, 2020. doi: 10.1016/j. foodres.2010.12.015Get.

CHANDI, G. K.; SOGI, D. S. Functional properties of rice bran protein concentrates. Journal of Food Engineering, v.79, n.2 p.592-597, 2007. Available from: <https://www.sciencedirect. com/science/article/abs/pii/S0260877406001956>. Accessed: Aug. 11, 2020. doi: 10.1016/j.jfoodeng.2006.02.018.

CHEMAT, F. et al. Applications of ultrasound in food technology: Processing, preservation and extraction. Ultrasonics Sonochemistry, v.18, n.4, p.813-835, 2011. Available from: $<$ https://www.sciencedirect.com/science/article/abs/pii/ S1350417710002385>. Accessed: Aug. 11, 2020. doi: 10.1016/j. ultsonch.2010.11.023.

CHITTAPALO, T.; NOOMHORM, A. Ultrasonic assisted alkali extraction of protein from defatted rice bran and properties of the protein concentrates. International Journal of Food Science and Technology, v.44, n.9, p.1843-1849, 2009 Available from: <https://ifst.onlinelibrary.wiley.com/doi/abs/10. 1111/j.1365-2621.2009.02009.x>. Accessed: Aug. 11, 2020. doi: 10.1111/j.1365-2621.2009.02009.x.

DAMODARAN, S. Aminoácidos, Peptídeos e Proteínas. In: DAMODARAN, S.; PARKIN, K. L.; FENNEMA, O. R. (Ed.) Química de Alimentos de Fennema. 4. ed. Porto Alegre: Artmed, 2010. p.179-262.

FAN, J. P. et al. Optimization of ionic liquid based ultrasonic assisted extraction of puerarin from Radix Puerariae Lobatae by response surface methodology. Food Chemistry, v.135, n.4, p.2299-2306, 2012. Available from: <https://www.sciencedirect com/science/article/abs/pii/S0308814612011508>. Accessed: Aug. 11, 2020. doi: 10.1016/j.foodchem.2012.07.038.

FILGUEIRAS, A. V. et al. Comparison of ultrasound-assisted extraction and microwave-assisted digestion for determination of magnesium, manganese and zinc in plant samples by flame atomic absorption spectrometry. Talanta, v.53, n.2, p.433-441, 2000 Available from: <https://www.sciencedirect.com/science/article/
abs/pii/S0039914000005105>. Accessed: Aug. 11, 2020. doi: 10.1016/S0039-9140(00)00510-5.

GNANASAMBANDAM, R.; HELTIARACHCHY, N. S. Protein concentrates from unstabilized and stabilized rice bran: preparation and properties. Journal of Food Science, v.60, n.5, p.1066-1069, 1995. Available from: <https://onlinelibrary.wiley.com/doi/ abs/10.1111/j.1365-2621.1995.tb06293.x>. Accessed: Aug. 11, 2020. doi: 10.1111/j.1365-2621.1995.tb06293.x.

GUPTA, S. et al. Effect of extraction temperature on functional properties of rice bran protein concentrates. International Journal of Food Engineering, v.4, n.2, 2008. Available from: $<$ https://www.degruyter.com/view/journals/ijfe/4/2/articleijfe.2008.4.2.1165.xml.xml>. Accessed: Aug. 11, 2020. doi: $10.2202 / 1556-3758.1165$

HAN, S. et al. Nutritional quality of rice bran protein in comparison to animal and vegetable protein. Food Chemistry, v.172, p.766769, 2015. Available from: <https://www.sciencedirect.com/ science/article/abs/pii/S030881461401512X>. Accessed: Aug. 11, 2020. doi: 10.1016/j.foodchem.2014.09.127.

HOU, F. et al. Alkali solution extraction of rice residue protein isolates: Influence of alkali concentration on protein functional, structural properties and lysinoalanine formation. Food Chemistry, v.218, p. 207-215, 2017. Available from: <https://www sciencedirect.com/journal/food-chemistry/vol/218/suppl/C $>$. Accessed: Aug. 11, 2020. doi: 10.1016/j.foodchem.2016.09.064.

$\mathrm{HU}, \mathrm{H}$. et al. Effects of ultrasound on structural and physical properties of soy protein isolate (SPI) dispersions. Food Hydrocolloids, v.30, n.2, p.647-655, 2013. Available from: $<$ https://www.sciencedirect.com/science/article/abs/pii/ S0268005X12001725>. Accessed: Aug. 11, 2020. doi: 10.1016/j. foodhyd.2012.08.001

JAMBRAK, A. R. et al. Effect of ultrasound treatment on solubility and foaming properties of whey protein suspensions. Journal of Food Engineering, v.86, n.2, p.281-287, 2008. Available from: <https://www.sciencedirect.com/science/article/abs/pii/ S0260877407005195>. Accessed: Aug. 11, 2020. doi: 10.1016/j. jfoodeng.2007.10.004.

LEE, W. T. et al. Research Approaches and Methods for Evaluating the Protein Quality of Human Foods Proposed by an FAO Expert Working Group in 2014. The Journal of Nutrition, v.146, n.5, p.929-932, 2016. Available from: <https://academic.oup.com/ jn/article/146/5/929/4589902>. Accessed: Aug. 11, 2020. doi: 10.3945/jn. 115.222109

LIN, M. J. Y. et al. Certain Functional properties of sunflower meal products. Journal of Food Science, v.39, p.368-370, 1974. Available from: <https://onlinelibrary.wiley.com/doi/ abs/10.1111/j.1365-2621.1974.tb02896.x>. Accessed: Aug. 11, 2020. doi: 10.1111/j.1365-2621.1974.tb02896.x.

LY, H. L. et al. Application of ultrasound to protein extraction from defatted rice bran. International Food Research Journal, v.25, n.2, p.695-701, 2018. Available from: <https:/www.scielo.br/ scielo.php?script $=$ sci arttext\&pid $=$ S0101-20612019000500324>. Accessed: Aug. 11, 2020. doi: 10.1590/fst.03918.

MILLER, D. D. Minerais. In: DAMODARAN, S.; PARKIN, K. .; FENNEMA, O. R. (Ed.). Química de Alimentos de Fennema. 4. ed. BOca Raton: CRC Press, 2010. p. 410-444. 
PHONGTHAI, S. et al. Ultrasonic-Assisted Extraction of Rice Bran Protein Using Response Surface Methodology. Journal of Food Biochemistry, v.41, n.2, 2016a. Available from: <https:// onlinelibrary.wiley.com/doi/abs/10.1111/jfbc.12314>. Accessed: Aug. 11, 2020. doi: 10.1111/jfbc. 12314 .

PHONGTHAI, S. et al. Optimization of microwave-assisted extraction of rice bran protein and its hydrolysates properties. Journal of Cereal Science, v.70, p.146-154, 2016b. Available from: <https://www.sciencedirect.com/science/article/abs/pii/ S0733521016301035>. Accessed: Aug. 11, 2020. doi: 10.1016/j. jes.2016.06.001.

PRATA, A. S.; SGARBIERI, V. C. Composition and physicochemical properties of two protein fractions of bovine blood serum. Ciência e Tecnologia de Alimentos, v.28, n.4, p.964-972, 2008. Available from: < https://www.scielo.br/scielo. php?script $=$ sci_abstract\&pid $=$ S0101-20612008000400032\&lng $=$ en $\& n r m=$ iso $>$. Accessed: Aug. 11, 2020. doi: 10.1590/S010120612008000400032.

ROMERO, M. V. Rice proteins. In: USTUNOL, Z. (Ed.). Applied Food Protein Chemistry. Wiley Blackweel, 2015. p.305-322.

SHEN, L. et al. Studies on tea protein extraction using alkaline and enzyme methods. Food Chemistry, v.107, n.2, p.929-938, 2008. Available from: <https:/www.sciencedirect.com/science/article/ abs/pii/S0308814607008436?via\%3Dihub>. Accessed: Aug. 11, 2020. doi: 10.1016/j.foodchem.2007.08.047.

TANG, S. et al. Physicochemical properties and functionality of rice bran protein hydrolyzate prepared from heat-stabilized defatted rice bran with the aid of enzymes. Journal of Food Science, v.68, n.1, p.152-157, 2003. Available from: $<$ https://onlinelibrary.wiley. com/doi/abs/10.1111/j.1365-2621.2003.tb14132.x>. Accessed: Aug. 11, 2020. doi: 10.1111/j.1365-2621.2003.tb14132.x.

WHO/FAO/UNU. Amino acid socring patterns. 1981. Available from: <http://www.fao.org/3/M3013E/M3013E00.htm>. Accessed: May, 6. 2020.

WHO/FAO/UNU. Protein and amino acid acid requirements in human nutrition. 2007. Available from: <https://apps.who. int/iris/bitstream/handle/10665/43411/WHO TRS 935 eng. pdf? sequence $=1 \&$ isAllowed $=y>$. Accessed: May, 6. $20 \overline{2} 0$.

YADAV, R. B. et al. Extraction, characterization and utilization of rice bran protein concentrate for biscuit making. British Food Journal, v.113, n.9, p.1173-1182, 2011. Available from: <https://www.emerald.com/insight/content/ doi/10.1108/00070701111174596/full/html>. Accessed: Aug. 11, 2020. doi: 10.1108/00070701111174596.

ZHANG, H. J. et al. Preparation and functional properties of rice bran proteins from heat-stabilized defatted rice bran. Food Research International, v.47, n.2, p.359-363, 2012. Available from: $\quad<$ https://www.sciencedirect.com/science/article/abs/pii/ S0963996911005084>. Accessed: Aug. 11, 2020. doi: 10.1016/j. foodres.2011.08.014.

ZHAO, G. et al. Ultrasound assisted extraction of carbohydrates from microalgae as feedstock for yeast fermentation. Bioresource Technology, v.128, p.337-344, 2013. Available from: $\quad<$ https://www.sciencedirect.com/science/article/abs/pii/ S0960852412015404>. Accessed: Aug. 11, 2020. doi: 10.1016/j. biortech.2012.10.038 